\title{
Rewriting of Children's Literature: Do We have a Universal Norm?
}

PRIYADA SHRIDHAR PADHYE

\section{Abstract}

This article envisages proving the universality of the norm of rewriting in the genre of Children's Literature and its translation. The article seeks to prove how re-writing is a phenomenon integral to the genre of children's literature. The author then goes on to prove how this norm is at play in even cultures as distant as the Indian and the German. Finally, attempt is made to identify the reasons for this norm. While proving the prevalence of this norm in the children's literature of the world, the article subtly reveals the power equations that are at play like societal structures, religious establishments and political forces (Itamar Even-Zohar). These, sometimes subtle and sometimes not so subtle forces, shed light on the scheming forces that shape the world of translation by playing a crucial role in deciding what gets translated, how it gets translated and why it gets translated when it does get translated. This paper envisages focusing on these forces of Translation with special reference to the translations of children's literature in the world.

Keywords: Rewriting, children's literature, Polysystem theory, politics of translation, Grimm's Fairy Tales, the Panchatantra.

\section{Introduction}

This article explores the universality of the norm of "rewriting" in Children's Literature and its translation. It is important here to briefly explain what the terms "norm" and "rewriting" mean in the context of this article. The term "norm" in this article should be simply understood as a rule (in 
opposition to an exception) and not in the way Gideon Toury uses it. When the term "rewriting" is used, it is meant to refer to all attempts, by the author or the translator- addition, deletion and appropriation of the content matter, change of form and the attempts to sanitize and erase textual content.

The phenomenon of rewriting with respect to the genre of Children's Literature and its translation will be discussed in two sections. The first section will investigate in general terms, how all literature for children and its translation, is basically an act of re-writing. The second section will deal with, what I would like to refer to as a "conscious and intentional rewriting", by the authors and translators of Children's Literature. "Conscious and intentional rewriting" is the act, where the authors and translators knowingly add, delete, appropriate, erase and sanitize the texts, with the intent of, what can be idiomatically referred to as, 'playing to the gallery' and 'serving - as- ordered' or to use Children's Literature and its translation as a tool to further a hidden personal agenda, which may be, among many others, of political, social and religious nature. The article will end with a few concluding remarks, in which attempt will be made to understand the reasons behind this phenomenon.

For the purpose of this article, I have selected two comparable works, one representative of the Children's Literature in the West and another representative of the Children's Literature of India. Representative of the Children's Literature in the West is the Children's and household Tales of the Grimm Brothers and representative of Indian Children's Literature is The Panchatantra. One reason for choosing these two works for investigation is their comparable success as children's literature in the world. Both the works have transcended cultures, languages and countries of the world and still continue to be translated widely. As Lanman puts it, the 
Panchatantra has made a "(...) triumphal progress from its native land over all the civilized parts of the globe" (1915 Preface: ix) and Dollerup maintains that the Grimm's Fairy Tales are "one of the most widely translated works of German Literature" (289: my translation). The other reason for choosing these two works is the fact that in terms of their spatial and temporal origin they have nothing in common. The book Children's and Household Tales was first published on German soil in 1812 whereas the Panchatantra dates back to the $5^{\text {th }}$ century and the oldest version was believed to have been written in Kashmir. This suits best to test the universality of the norm of rewriting.

Let me begin by proving that rewriting, as a phenomenon, is common to both the Grimm's Tales as well as the Panchatantra. My point of departure is that there is nothing like an original where children's literature is concerned. All children's tales, as we know them, are re-worked and rewritten. Let us first consider the case of the Grimm's Tales. The Grimm's Fairy Tales have the indelible mark of their authors Jacob and Wilhelm Grimm and have been widely, though erroneously, perceived to be German. If we study the historical and social setting of their collection, we realize that they were rewritings of oral renditions. The brothers were born at a time when Germany under Napoleon was witnessing a surge of nationalism. Their efforts to create a national literature drove them to collect folk tales and legends of Germany. Their association with people like Karl von Savigny and Clemens Brentano and their especially Jacob's, interest in the Norwegian mythology of Norse, to which one can attribute the presence of nature and the fantasy elements in their stories, all contributed to giving the tales their specific character (Dollerup: 3-4). The stories were collected in the spirit of $19^{\text {th }}$ century Romanticism-the return to sources and nature (Shavit 
1983: 64). Their main source, amongst many others, was the Wild and the Hassenpflug families (Zipes: 10). Most of the storytellers like the Hassenpflug family were of French origin (Zipes: 11). This is particularly true of the tale "Little Red Riding Hood", to which I return later in the article. It was known much prior to the Grimm's version, as one of the tales in Charles Perrault's Contes, a collection of fairy tales, which was published by Perrault in 1697. So what came to be known as German fairy tales were actually inspired by the Norwegian mythology and believed to be French in their origin. This poses the question: How German is the Grimm's fairy tales and should they not be considered as re-writings of oral renditions of Norwegian and French tales?

The same conclusion, albeit in a different light, is true of the Panchatantra. If one takes up any translation, old or new, in Indian or foreign languages of the Panchatantra, it is often mentioned that the translation is from the original Sanskrit book written by Vishnu Sharma. Research has established that Vishnu Sharma is a pseudonym and a school of thought believes that the Panchatantra was ghost-written by Chanakya. Even if we are not sure today whether and how the Panchatantra tales were written or collected, there exist today multiple Sanskrit versions/ re-writings of this great work like the oldest and probably the most original Kashmiri Tantrakhyayika (written between $300 \mathrm{BC}$ and $570 \mathrm{AD}$ ), Purnabhadra's Panchakhyanaka, Ksemendra's Brhatkathamanjari, Somadeva's Bhrathkathasaritasagar, and the list goes on and $\mathrm{on}^{22}$. The versions which are available to

22 In the year 1910 the German Indologist Johannes Hertel was commissioned by the Philosophy department of the University of Strasbourg, in their capacity as administrators of the Lamey Foundation to undertake a study which would be dedicated to researching all the prevailing versions of the Panchatantra in the world. His book "Das 
us today are old incomplete manuscripts in the form of fragments. There are no "originals" to refer to. Indologists and Philologists study multiple versions of the Panchatantra to understand which stories or parts of the verses and prose can be traced to this or that version. It is also interesting to observe that translations of the Panchatantra in Indian and foreign languages often simply mention "translated from the Sanskrit" $" 23$, as if to suggest that there is only one Panchatantra written in Sanskrit, from which the translation has been done. This again emphasizes the fact that even the Panchatantra is in fact a case of a rewriting which has happened over the years and so it is difficult to speak of the "original" with regard to the Panchatantra.

To conclude this section, all children's literature, in one way or the other, is a rewriting of stories that were handed down orally from generation to generation. Even in case of children's literature with canonical status like the Grimm's Fairy Tales, the right of the brothers to authorship and their claim to proprietorship is questionable. In the case of the Panchatantra, which version is the "original" and which has

Pancatantra: seine Geschichte und seine Verbreitung" compares all the available versions and translations of the work in the world and he also attempts to identify which versions are corrupted and which translations can be traced back to certain original works.

${ }^{23}$ Though there are many versions of the Panchatantra, no translation mentions which version was used for the translation. I cite two examples of famous translators. One is Richard Schmidt and the other is Theodor Benfey. Schmidt's translation was published in 1901 simply mentions "a collection of old Indian fairy tales, translated for the first time" (my translation). Theodor Benfey's book was published in 1859, has the title "The Panchatantra: Five books of Indian fables, fairy tales and stories translated from the Sanskrit" (my translation). No translation mentions which book was used as the original giving the impression that there existed only one book called the Panchatantra. 
been rewritten has long been and continues to be a topic of research.

Having discussed the phenomenon of rewriting of children's literature in a broad sense, I will now devote the next section to, what I have earlier termed as "conscious and intentional rewriting" of these works by their authors and translators, an act for which a stronger word like manipulation may not be totally wrong, because it deals with adding, deleting, appropriating the content for vested interests which range from religious, commercial, political to ideological. This conscious and intentional rewriting of children's literature stems from the need for acceptance and approval by the players involved in the process. These myriad players range from the parents who read the stories to the children and the pedagogues and ideologues who decide what is appropriate for the child on the one hand, to the commissioners of the translations who may range from publishing houses to religious establishments on the other hand. A few examples to prove the point are being presented.

We are aware of the fact that from 1812 to 1857 the Grimm's Tales had been edited by Wilhelm Grimm multiple times. The editing, or a new writing of the tales, in my opinion, was done with a view to make the tales acceptable to the people and the times. A few examples will prove the point for which a brief overview of the historicity of children's literature in the West is necessary.

The first written children's literature in the West is dated late $17^{\text {th }}$ century. Early $17^{\text {th }}$ century Europe witnessed a paradigm change in how children were educated. The system of apprenticeship for learning a trade had been in operation till the $17^{\text {th }}$ century. This system was replaced by establishment of schools. The schools were mainly run by the church (Shavit 
2007: 38-40). The children's literature of the time is marked by educational values and not fantasy, as even fairy tales were not considered appropriate reading material for children back then, because of the presence of violence in most, as well as the sexual references in them. Hence presence of sexual references in children's literature was prohibited. Wilhelm Grimm's editing of the tale "Little Red Riding Hood" as well as the tale "Rapunzel", it appears, was undertaken with the aim of making the tale acceptable by adhering to this unwritten norm. By the time the Children's and Household Tales came on the scene in 1812, there seemed to be concrete dos and don'ts with respect to children's literature. There were six editions of their book which was first published in 1812. New editions followed in the ensuing years in 1819, 1837, 1840, 1843, 1850 till the final one in 1857. One finds many differences in the stories if one compares the first edition in 1812 and the last edition in 1857. Wilhelm Grimm, who edited the fairy tales so as to tailor them to meet the approval of the adults and the church, adapted them to the Zeitgeist, which was marked by Christian ideals, nationalist fervour, rapid industrialization and urbanization and the establishment of the nuclear family. He rewrote the content of the stories as narrated to the Grimm Brothers by their narrators. The tale Little Red Riding Hood would be one such case in point. It was written by Perrault to caution small country girls of city bred men who take advantage of the girls with their sweet talk $^{24}$. The satirical and ironical levels of the text enabled Perrault to play with the symbol of the wolf, which in light of the moral of the story, stands for "gentleman of the town" who does not hesitate to take advantage of poor, innocent country

\footnotetext{
${ }^{24}$ Refer to the first chapter of Shavit Zohar's book titled "Poetics of Children's Literature". The chapter is called 'The Notion of Childhood and Texts for the Child. Charles Perrault
} 
girls. The theme of gentlemen who take advantage of little country girls goes well with the presence of erotic elements in the story. In the Grimm's version, the erotic elements had to be done away with and so the text was rewritten. The child became the narrator and in keeping with the ideals of a child in the early $20^{\text {th }}$ century, the narration was with innocence. In Perrault's version, the child is devoured by the wolf, because he wanted to drive home his point of cautioning the innocent girls but in the Grimm's version there are two endings and in both the child is saved (Shavit 1983: 62).

Another instance where Wilhelm changed the content of the story to do away with sexual undertones in the story is the story Rapunzel (Zipes: 13). In their 1812 version of "Kinderund Hausmärchen" on page 41, Rapunzel has the following conversation with the witch which unmistakably has sexual undertones, 'Tell me Mrs. Gothel, my clothes are becoming tighter and do not fit me' (my translation).

In the story, this sentence reveals that Rapunzel is pregnant. This sentence in the story has a function which is vital for the plot because it is this naïve remark by Rapunzel that tells the witch that somebody has been visiting Rapunzel. The same was changed in course of time and in the 1857 edition it disappears. In its place, the following sentence is found on page 68: 'Tell me Mrs. Gothel, how come I find you heavier to haul than the Prince; he is here in a moment' (my translation).

As regards adapting the stories to the values of the times, there are instances of changes made with that view in mind too. After the war against Napoleon (1810-1815), there followed a period of industrialization and urbanization throughout Europe (Dollerup: 6). The nuclear family became a norm as many people shifted to the towns. Family values were important. In the 1815 edition, in the stories "Snow white" and "Hansel and 
Gretel" (Grimm 1815: 49), it is the mother who causes the children harm. Keeping the nuclear family set up in mind, this had to be changed to the step mother taking the place of the mother. The idea of one's own mother harming one's child would have been unpalatable to the people of the time.

Content of the Grimm's Fairy Tales was adapted more and more till the last edition in 1857 not only had met with approval but had also developed into what can be described as a peculiar style of the Grimm's tales.

This conscious rewriting of the Grimm's Tales was done with an eye on what was considered to be pedagogically "correct content". This stamp of adult approval contributed to their success. Another aspect that could have played a role in the rewriting of these stories could also be the fact that the ability of the child had been taken into consideration. In the case of the Grimm's Fairy Tales, the child was unmistakably the "intended reader" (Shavit 1983: 60). Hence violence and sexual references had been probably thought to be difficult for the children to understand.

To test the universality of the norm of "intentional and conscious rewriting" I would now like to take an example of such an instance in case of the Panchatantra. One example of the same in an Indian language and one in a non-Indian language will suffice to prove the point.

The Panchatantra tales exhibit massive rewriting, not out of any pedagogical considerations or for seeking adult approval. The rewriting of the Panchatantra was, in my opinion, an "interventionist act". The translations of the work studied in languages known to the author of this article reveal that the translations of the Panchatantra were often commissioned by religious and political institutions and personalities. The tales have been translated in practically all languages of the world 
and in all cultures, Semitic as well as non-Semitic. It is worth noting that very often the translators were representatives of religions establishments and had been converted from one religion to other. The enthusiasm of the translators for their new religions was revealed in the religious touch they gave to the translation of the Panchatantra and also in the fact that they dedicated the translations to the higher authorities of their adopted religions. One such translator was Johannes von Capua. Capua was a Jew, who had been converted to Christianity. He dedicated the translation to the Cardinal Matthäus Rubens Ursinus (Hertel 396). He translated it between 1263 and 1278 from a Hebrew text into Latin. His translation was titled Directorium vitae humanae. Another such translator was Anton von Pforr, who was a member of the clergy. He was the Vicar of Jechtingen and had been commissioned by the Count Eberhard of Württemberg (Wegener 152) to translate Capua's Latin version of the Panchatantra into German. The translation of Johannes von Capua's text into German is called "The book of examples of old wisdom" (my translation of the German title - Das Buch der Beispiele alter Weisen) and it is dated 1480. It was this book that was used for the translations into Danish, Dutch and Icelandic (Hertel 398). The translation was also used as a relay for the more recent translation (published in 1926) of the work into German by Hans Wegener. Wegener mentions in the afterword that, he (Anto von Pforr) "satisfied himself by giving the interpretation a Christian touch' (my translation) (Wegener: 151).

In India the Panchatantra was extensively translated into all Indian languages. The spread of this work to the southern part of India has been attributed to the Marathi translations which used the Jain texts as original. So Marathi was the gateway 
language for the translation in the south Indian languages and the Jain texts worked as relays (Hertel: 250).

An excellent example of a conscious and intentional rewriting of the Panchatantra is the Bhagvatisatish. This is a translation in the Marathi language, in fact, in a dialect of Marathi language spoken near Aurangabad. The translator was called Nirmala Pathak and belonged to the Bhagwat sect. The translation has used a couple of Jain texts as the original. Because the Jain texts were always written in a way that they advocated the tenets of the Jain religion. Nirmala Pathak had to intervene and modify the content so as to make it suitable to the tenets of the Bhagwat sect, of which he was a disciple. Not only was the content changed but also the form. Bhagvatisatish has been written in the Ovi meter, so that it gains more acceptances among the people (Hertel 262-267). When it came to content of the text, one finds that there were deletions, additions modifications as well as erasure of certain elements, the former being more on a superficial level of changing the names of places and the protagonists and the latter being of a serious nature. A few examples of the former are, changing the name of the city to Mahitala from Mahilaropya, doing away with the character of the King Amarsakti and naming the sons of the King Sisukti, Rudrasakti and Anekasakti instead of Vasusakti, Ugrasakti and Anantasakti. Changes of this nature are, what I would like to call, superficial in nature (Hertel 274275).

Changes which were, in my opinion serious in nature, where the discourse of the original(s) was changed, will be discussed now. In my opinion, the Jain treatment of the Panchatantra was undertaken with a view to emphasize the Jain doctrine of Karma, so there were never references to God in the stories. This was changed by Nirmala Pathak in the Bhagwatisatish. The translator avoided all references where the power of the 
"Karma" was highlighted and praised at the cost of the power of the Gods. Nirmala Pathak instead highlights the power of Gods and Brahmins. The story in Bhagwatisatish begins with the queen worrying about her sons who had received no learning and invoking "God" to help her (Hertel 274-275). In the story of the monkey and the crocodile the monkey thanks "God" in the end for saving his life (Hertel 278).

In the Bhagwatisatish the translator also sanitizes the text of Jain beliefs and appropriates the text so as to suit the tenets of the Bhagwat sect (Hertel 273). The Jain authors and translators were in the habit of highlighting the moral of the story, which was a "karma moral" at the end of the story. Since the translator Nirmala Pathak wanted to avoid mentioning the Jain moral of "karma", some stories in the Bhawatisatish end abruptly, for instance, story 4 of the weaver Somilaka in the second Book (Hertel 277f).

I will take one more example to prove my point and come to the end of this section. In book III, story IV, there is the story of the king Mukhya. He is very hungry at night and eats a baby snake. Then he falls ill. So he relinquishes the throne to his son and sets off to Benares. Moral, according to the Jain version, is that one should not eat after sunset otherwise there will be consequences. This, as we know, is one of the Jain principles. The Marathi translation does not mention the moral at the end of the story (Hertel: 278), hence, this story too ends very abruptly.

\section{Conclusion}

There is a groundswell of difference between the tradition of written Children's Literature and its translation in India and the West. In these concluding remarks I would like to briefly discuss the major differences and conclude this article by presenting some deliberations on the reasons for the universal 
prevalence of the norm of rewriting in the genre of Children's Literature and its translation.

The first essential difference is that stories are narrated to children in India as against read to in the West. Though the children's literature in India dates back to even before the $5^{\text {th }}$ century, in the written form, like the case of the Panchatantra, as against in the West which begins sometime in the $17^{\text {th }}$ century, stories continue to be narrated at meals by a grandmother, or a cousin in India. Writing did not necessarily fix them (Ramanujan: 448) as it did in the West.

The children's literature in India grew out of the canonical texts like the Mahabharata, the Ramayana, the Panchatantra, the Buddhist Jatakas and the Kathasaritasagara among other books whereas in the West it was created and hastily put together because there was a "gap" in the literary polysystem at the time (Even-Zohar). This "gap" was filled with books modelled on the lines of chapbooks, which already occupied a peripheral status in the adult literary polysystem, which was one of the reasons, why the children's literature in the West suffered a peripheral status (Shavit 2007: 38-40) ${ }^{25}$. There is no evidence of such marginality of children's literature in the Indian context.

If the content of what is Children's Literature in the West and India is compared, one finds many differences. The Grimm's

${ }^{25}$ Shavit has done in-depth research on the status of children's literature in the West. She maintains that the children's literature in the West suffered an inferior status, one because it was developed from cheap chapbooks which already occupied a peripheral position in the literary polysystem, second because the newly developed notion of childhood drew not only literature but also the clothing and the language from the lower class. The highbrow society did not want to be identified with children's literature as it was considered to have an inferior status in the European literary polysystem. 
Tales essentially preach the existing discourse of the time, they preach what was considered as right. This has been proven in the article by the fact that the stories were sanitized of sexual references. The stories do not, so much as, suggest an alternative to the prevailing discourse whereas the Indian tales often "question and comment on official notions and myths of the culture (...) show the underbelly of the official virtues" (Ramanujan: 469). Sexual content was not a taboo. The Panchatantra contains many sexual references (Book 1 story no.3, the story of the businessman Dantil and story no.4, the story of Ashadabhuti and Devsharman) and my investigation so far shows that there have not been any attempts to erase them in the translations in Indian and in non-Indian languages.

Notwithstanding the above-mentioned differences the norm of rewriting, intentional or otherwise, is common to both the systems of children's literature. Is it possible to suggest the reasons for the universality of this norm? In this last section of the concluding observations I would like to deliberate on a few reasons for this phenomenon.

One of the reasons for the prevalence of this norm in the West is the unavailability of literature, written exclusively for children, when it was needed. To fill this vacuum in the literary polysystem the genre had to borrow heavily from existing adult literature which had ideological and religious focus and was written in a sophisticated style. A few examples of such in the West are Gulliver's Travels (1726), Robinson Crusoe (1719) and Alice's Adventures in Wonderland (1865). All these books were meant for adult consumption. Gulliver's Travels was a satire on human nature, Robinson Crusoe was a tale filled with religious connotations by Defoe and Alice's Adventures in Wonderland was originally a tale which plays with logic. When these books came to be adapted for children 
they had to be rewritten by doing away with satire, ideological undertones and sophisticated writing style.

The rewriting of Indian children's literature, as seen in the case of the Panchatantra, seems to have been done for religious reasons. The commissioning agents in the form of religious establishments and the religious convictions and leanings of the translators seemed to play a major role in the fact that the Panchatantra was rewritten.

I conclude this article with the words that rewriting is a universal phenomenon in the writing and translation of children's literature though the reasons may vary from culture to culture.

\section{References}

DOLlerup, CAY. 1999. Tales and Translation: The Grimm Tales from Pan-Germanic Narratives to Shared International Fairytales. Amsterdam/Philadelphia: John Benjamins B.V.

DHARWADKER, VinAY (ed.). 1999. The Collected Essays of A. K. Ramanujan. New Delhi: Oxford University Press.

Even-ZOHAR, ItAMAR. 1978. The Position of Translated Literature within the Literary Polysystem. In. Papers in Historical Poetics, 21-27. Israel: University Publishing Projects.

GRIMM, JACOB; and GRIMM, WILHELM. 1977. Kinder und Hausmärchen. Gesammelt Durch Die Brüder Grimm. München: Winkler.

GRIMM, JACOB UND WILHELM. 1812. Kinder-und Hausmärchen., Band 1. Berlin S. 38-43.

GRIMM, JACOB UND WILHELM. 1857. Kinder- und Hausmärchen. Band 1. Göttingen, S. 65.

Hertel, Johannes. 1914. Das Pancatantra seine Geschichte und seine Verbreitung. Leipzig und Berlin: Vlg. Von B. G. 
Priyada Shridhar Padhye

Teubner, Print. https://archive.org/details/daspancatantrase00hert (5Jan.2018).

LAnMan, Charles (ed.). 1912. The Panchatantra- Text of Purnabhadra and its relation to texts of allied recensions as shown in parallel specimens by Dr. Johannes Hertel. Cambridge: Harvard UP. Print. Harvard Oriental Series Volume 13.

LANMAN, CHARles (ed.). 1915. The Panchatantra: A Collection of Ancient Hindu Tales in its Oldest Recension, the Kashmirian, entitled Tantrakhyayika. Cambridge: Harvard UP, Harvard Oriental Series Volume 14. http://books.google.com/ 12/Jan.2018

LATHEY, GILLIAN. 2009. Children's Literature. In Baker, Mona; Saldanha, Gabriela; (eds.), Routledge Encyclopedia of Translation Studies. Routledge. Second edition, USA: Routledge. 31-34.

Ramanujan, A. K. 1999. Telling Tales. In. Dharwadker, Vinay (ed.), The Collected Essays of A. K. Ramanujan, 448-462. New Delhi: Oxford University Press.

Ramanujan, A. K. 1999. Tell It to the Walls: On Folktales in Indian Culture. In Vinay Dharwadker (ed.), The Collected Essays of A. K. Ramanujan, 463-484. New Delhi: Oxford University Press.

SCHMIDT, RICHARD. 1901. Das Pancatantram (Textus Ornatior) Eine Altindische Märchensammlung zum ersten Male übersetzt. Leipzig: Lotus Verlag

SHAVIT, ZOHAR. 1983. The Notion of Childhood and the Child as Implied Reader (Test Case "Little Red Riding Hood). Journal of Research and Development in Education, 16(3), 60-67.

SHAVIT, ZOHAR. 1986. Poetics of Children's Literature, Athens and London: The University of Georgia Press.

Shavit, ZOHAR. 2007. Freedom in Marginality. The Constraints of Writing for Children, Resulting from Its 
Rewriting of Children's Literature:...

Marginal Position. In Azevdo, Fernando, Joaquim Machado de Araújo (eds.), Imaginário, Identidades $e$ Margens, Estudos em torno da Literatura Infanto-Juvenil Gailivro:Serzedo 35-47.

Wegenter, HAns (ed.). 1925. Bidpai: Das Buch der Beispiele alter Weisen. Berlin:Wegweiser Vlg.G.m.b.H., Print. http://archive.org/details/bidpaidas00pfor 12/1/2018.

ZIPES, JACK. 1988. The Brothers Grimm. From Enchanted Forests to the Modern World. Inc. USA: Routledge, Chapman and Hall. 